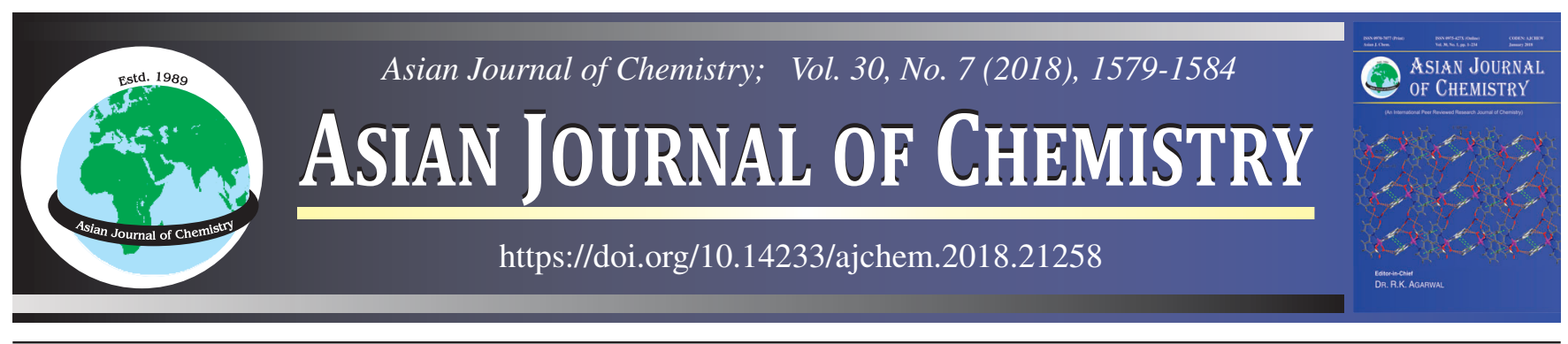

\title{
Isolation and Characterization of Flavonoid from Methanolic Extract of Mirabilis jalapa Linn. Tuber and Evaluation of its Cardioprotective Property
}

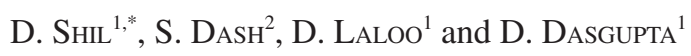

${ }^{1}$ Girijananda Chowdhury Institute of Pharmaceutical Science, Azara, Hathkhowapara, Guwahati-781 017, India

${ }^{2}$ Regional Institute of Pharmaceutical Science and Technology, Agartala-799 006, India

*Corresponding author: E-mail: dibyendu0684@ rediffmail.com

Received: 30 January 2018;

Accepted: 15 March 2018;

Published online: 31 May 2018;

AJC-18934

The aim of the study is to isolate and characterization of bioconstituent present in methanolic extract of Mirabilis jalapa L. tuber and also
evaluate the cardioprotective property of the extract as well as isolated compound from the extract. The bioactive constituent flavonoid
was isolated from methanolic extract through flash chromatography technique by using solvent system ethyl acetate and methanol. The
chemical structure of compound was confirmed on the basis of spectroscopy analysis and identified as $2-\left(3^{\prime}, 4^{\prime}\right.$-dihydroxy phenyl)-3,5,7-
trihydroxy chromen 4-one. Administration of Mirabilis jalapa extract in higher dose 200 and $400 \mathrm{mg} / \mathrm{kg}$ b.w. and isolated compound to
doxorubicin-intoxicated rats demonstrated prominent reduction in serum biomarker enzymes, normalization of serum lipid profiles. Also,
significant modulation of malondialdehyde (MDA), endogenous non-enzymatic (GSH) and enzymatic (SOD and CAT) antioxidant and
detoxification systems compared to doxorubicin control rats. This was achieved due to presence of flavonoid in the methanolic extract of
Mirabilis jalapa L. tuber. |

Keywords: Mirabilis jalapa L. tuber, Flavonoid, Doxorubicin, Cardioprotective.

L

\section{INTRODUCTION}

Mirabilis jalapa Linn. commonly known as Marvel of Peru or four o' clock flower belonging to the family Nyctaginaceae is the herbaceous plant. Traditionally the plant parts are used as antidysenteric, antiparasitic, carminative, digestive stimulant, tonic, vermifuge, wound healer, cathartic, etc. [1]. The roots and tubers have aphrodisiac, diuretic and purgative properties [2]. In Ayurvedic system the plant is well known for its use in treating boils, inflammations, constipation, diabetes, urinary disorders and hypertension. Dried flowers are used as a snuff for headaches, fungal infection and root decoction to wash wounds, treat skin afflictions as leprosy [3,4].

It is reported that the root of Mirabilis jalapa contain phytoconstituents such as alkaloids, glycosides, phytosterol and phenolic compounds [5]. But the evidences were found in the literature on the root part of this plant which is inadequate to consider as standard. Therefore, the effort was carried out to isolate and characterize the bioactive constituent from the methanolic extract of Mirabilis jalapa L. tuber and also establish the cardiopotective property of the tuber, which claimed by folk people of north east India. To establish cardiopotective property, the anticancer drug doxorubicin was used as positive control to produce cardiotoxicity in rats. It can leads to conges- tive heart failure, increase free radical formation, increase chlolesterol, triglyceride, low-density lipoprotein (LDL), decrease activity of $\mathrm{Na}^{+}-\mathrm{K}^{+}$adenosine triphosphate, etc. [6].

\section{EXPERIMENTAL}

Tubers of Mirabilis jalapa were collected from local area of Kamrup district, India and authenticated by Dr. P.P. Baruah, Department of Botany, Gauhati University, India. The voucher specimen of Mirabilis jalapa tuberous root (Acc no. 18176) were kept at the Department of Pharmacognosy, Girijananda Chowdhury Institute of Pharmaceutical Sciences, Guwahati, India for future reference. The plant material was process and subjected to washing with running water, dried in shade for 10- 15 days and stored in air tight containers until used.

Preparation of extract: The dried tubers were subjected to size reduction. About $1 \mathrm{~kg}$ of crude powder drug was subjected to hot percolation with petroleum ether for $72 \mathrm{~h}$ to take out fatty material followed by cold maceration at room temperature with different solvent by increasing polarity such as benzene, diethyl ether, chloroform, acetone, ethyl acetate and $95 \%$ methanol for about $48 \mathrm{~h}$ with frequent shaking up to $6 \mathrm{~h}$. Extracts were then filtered, concentrated under reduced pressure in rotary evaporator (Buchi India Pvt. Ltd.) at $40{ }^{\circ} \mathrm{C}$ and stored 
in a desiccator until further compare to all other extracts methanolic extract showed the maximum quantity i.e. $10 \mathrm{~g}$ [7]. All the extracts were subjected to quantitative chemical tests as describe in reference books to identify the presence of different metabolites [7,8].

Isolation of bioactive constituents: Sample of each extracts were chromatographed on TLC [9] and found that methanolic extract showed the presence of flavonoid when eluted with ethyl acetate:methanol (7:3). For the separation of flavonoid, about $10 \mathrm{~g}$ of sample of Mirabilis jalapa tuber was further chromatographed in flash chromagraphy by using same eluent as TLC [10]. The fractions with same $R_{f}$ value on TLC were pooled together and evaporated to dryness, which was crystallized to give fine powdered crystals. The structure of the isolated compound has been elucidated by DSC, UV, mass, FTIR, CHN analysis and NMR spectra.

Experimental animal: Experimental works were carried out with the guidelines set by CPCSEA and were approved by the Institutional Animal Ethical Committee (GIPS/IAEC/Phd/ 2015/01). Female swiss albino mice of weighed between 20$25 \mathrm{~g}$ were housed and the standard conditions viz. $22 \pm 3{ }^{\circ} \mathrm{C}$, $50 \pm 10 \%$ humidity, $12 \mathrm{~h}$ interval light and dark phase were properly maintained and standard diet were followed as per the CPCSEA guideline.

Acute toxicity study: The methanolic extract of Mirabilis jalapa tuber was administered at of different doses of 2000 and $5000 \mathrm{mg} / \mathrm{kg}$ bw p.o. to overnight fasted experimental mice as suggested in OECD Guidelines 425 [11]. The animal behavioural changes and mortality, abnormalities were observed next $24 \mathrm{~h}$ and then recorded upto 14 days.

Selection of dose: After performing the acute toxicity studies, it was found that there was no mortality at the dose of $2000 \mathrm{mg} / \mathrm{kg}$ b.w. as well as $5000 \mathrm{mg} / \mathrm{kg}$ b.w. of Mirabilis jalapa tuber. Therefore, dose optimization was done and 100, 200 and $400 \mathrm{mg} / \mathrm{kg}$ p.o. were selected for the experimental study. For the oral dose optimization of isolated compound of Mirabilis jalapa tuber, the dose were calculated based on the percentage yield of isolated compound of Mirabilis jalapa $(2.78 \% \mathrm{w} / \mathrm{w})$ calculated in terms of the minimum effective dose of Mirabilis jalapa tuber $(200 \mathrm{mg} / \mathrm{kg}$, p.o.) that produced significant cardioprotective activity [12]. Therefore, in the present study, dose for the oral administration of isolated compound of Mirabilis jalapa was selected at $(5.56 \mathrm{mg} / \mathrm{kg}$ p.o.) for the experimental study.

Doxorubicin induced cardiotixicity in rats: Thirty six number of rats were divided into 6 groups $(n=6)$. Group I were served as doxorubicin control (dox control) received 5 $\mathrm{mg} / \mathrm{kg}$ bw i.p. Group II serve as normal control receive normal saline at $5 \mathrm{~mL} / \mathrm{kg}$ orally. Group III, IV and V were given Mirabilis jalapa tuber and group VI was given isolated compound from Mirabilis jalapa at the dose 100, 200, $400 \mathrm{mg} / \mathrm{kg}$ and 5.56 $\mathrm{mg} / \mathrm{kg}$ b.w./d/p.o accordingly for 21 days. Except group II doxorubicin was administered to all groups of animals in three equal injection on the 7th, 14th, 21st days for a total cumulative dose of $15 \mathrm{mg} / \mathrm{kg}$ b.w. i.p. [13].

Biochemical estimation from serum: After $24 \mathrm{~h}$, the last treated blood sample was collected by cardiac puncture from all groups of rats. Serum sample were separated for the estimation of the presence of different enzymes such as lactate dehydrogenase (LDH) [14], creatine phosphokinase (CPK) [15], aspartate transaminase (AST) [16], alanine transaminase (ALT). Lipid profile like total cholesterol, total triglycerides (TGL), high density lipoproteins (HDL) and low density lipoproteins (LDL) [17]. All the analyses were performed with commercially available kits based on the references using analyzer [18].

Preparation of heart tissue for estimation of oxidative stress marker: After collection of blood all the rats were sacrificed by cervical dislocation, the heart tissues were dissected immediately and homogenized with chilled $0.05 \mathrm{M}$ phosphate buffer for 10 times at $\mathrm{pH} 7.4$ in Teflon glass homogenizer and the homogenate was centrifuged at $1000 \mathrm{rpm} 4^{\circ} \mathrm{C}$ for $3 \mathrm{~min}$ and the supernatant divided into two portions [19], one of which was used for measurement of lipid peroxidation (LPO) [20]. The remaining supernatant was again centrifuged at $12,000 \mathrm{rpm}$ at $4{ }^{\circ} \mathrm{C}$ for $15 \mathrm{~min}$ and used for the measurement of superoxide dismutase (SOD) [21], catalase (CAT) [22] and glutathione (GSH) [23].

Histopathological studies: Hearts were removed from the experimental animals and kept in $10 \%$ formalin solution. The isolated heart is then processed for section cutting is about $5 \mu \mathrm{m}$ thickness by using microtome and stained with hematoxylin and eosin ( $\mathrm{H}$ and $\mathrm{E}$ ) reagents and observed by light microscope to evaluate myocardium injury [13].

Statistical analysis: Results were expressed as mean value \pm SEM. Data were analyzed incorporating GraphPad Prism 5 software and all statistical comparison were made using one way analysis of variance (ANOVA) followed by Dunnet's test post hoc analysis. Results were articulated where $\mathrm{P}$ values < 0.05 was considered statistically significant as compared to control group.

\section{RESULTS AND DISCUSSION}

The present study was aimed to isolate and characterized the bioactive constituent from methanolic extract of Mirabilis jalapa tuber. It was observed that methanolic extract produces the maximum percentage yield $(15 \%)$ of the extract followed by ethyl acetate $(12 \%)$ and chloroform $(9.2 \%)$ as solvents. The results from the preliminary phytochemical screening of different extract of Mirabilis jalapa tuberous root showed the presence of phyto-costituents like alkaloids, carbohydrate, glycosides, steroids, saponins, phenolics and flavonoids.

Isolation and characterization of compound: The fractions no. 25-38 obtained from flash chromatography showed the same $R_{f}$ value $\left(R_{f}=0.33\right)$ on TLC with yellowish orange colour on spraying of ferric chloride reagent which was then crystallized from methanol to give fine yellow powdered crystals and also showed reddish pink colour with $\mathrm{Mg}+\mathrm{HCl}$ (Sinoda reagent), which identified as flavonoid compound. The yield is $2.78 \% \mathrm{w} / \mathrm{w}, \mathrm{m} . \mathrm{p}$. is $317^{\circ} \mathrm{C}$, ESI-MS spectrum (positive ion mode) showed the presence of base peak at $\mathrm{m} / \mathrm{z} 301.12$ indicating the molecular weight of compound is 301 .

Infrared spectrum of the compound confirmed the presence of -OH group $\left(3253 \mathrm{~cm}^{-1}\right)$, conjugated carbonyl group $\left(1661 \mathrm{~cm}^{-1}\right)$ and aromatic C-C (1605 $\left.\mathrm{cm}^{-1}\right)$. CHNS analysis revealed that carbon found to be $52.208 \%$, hydrogen found to be $4.181 \%$ and oxygen found to be $43.61 \%$.

The compound showed strong absorption at $365 \mathrm{~nm}$ in its spectrum implied the presence of phenolic aromatic rings. 
TABLE-1

UV SPECTRAL DATA OF COMPOUND ISOLATED FROM METHANOLIC EXTRACT OF TUBEROUS ROOT OF Mirabilis jalapa Linn

\begin{tabular}{|c|c|c|c|}
\hline Preparation & $\begin{array}{l}\lambda_{\max }(\mathrm{nm}) \text { of } \\
\text { compound }\end{array}$ & Spectral effect & Structural diagnosis \\
\hline Methanolic solution of compound & 365,257 & - & Flavone-3-ol \\
\hline Methanolic solution of compound +3 drops of sodium methoxide solution & 400 & $35 \mathrm{~nm}$ shift in Band I & $4^{\prime}-\mathrm{C}=\mathrm{O}$ \\
\hline Methanolic solution of compound +6 drops of aluminium chloride & 385,263 & $20 \mathrm{~nm}$ Shift in Band I & 5-OH Free \\
\hline $\begin{array}{l}\text { Methanolic solution of compound }+6 \text { drops of aluminium chloride and } \\
3 \text { drops of hydrochloric acid }\end{array}$ & 390,268 & $25 \mathrm{~nm}$ shift in Band I & Presence of di-OH in $\mathrm{B}$ ring \\
\hline Methanolic solution of compound + powdered $\mathrm{NaOAc}$ & 257 & $\begin{array}{l}\text { Lack of shift in } \\
\text { Band II }\end{array}$ & $\begin{array}{l}\text { Absence of free 7-hydroxyl } \\
\text { group }\end{array}$ \\
\hline
\end{tabular}

The methanolic solution of compound exhibited typical UV absorption characteristics after the addition of various shifting reagents. The UV spectrum showed absorption bands reagents shifts of the compound to be a 7 -substituted derivative. The absence of free 7-hydroxyl group in the compound was observed in lack of shift of band II in the presence of NaOAc (Table-1).

The ${ }^{1} \mathrm{H}$ NMR spectrum (Table-2) of the compound was exhibited the singlet at $2.50 \mathrm{ppm}$ indicated the presence of $1-\mathrm{H}$ at $\mathrm{C}-6$ position. The singlet peak at $3.53 \mathrm{ppm}$ indicates the presence of 1- $\mathrm{H}$ at $\mathrm{C}-8$ position. The presence of lone pair electron on the oxygen atom of $\mathrm{OH}$ ion make the $\mathrm{OH}$ proton deshielded as a result the $\mathrm{OH}$ peak appeared at down field. The double peak at $6.19 \mathrm{ppm}$ is due to the $\mathrm{C}-\mathrm{OH}$ proton at $\mathrm{C}-3$ position $(J=$ $1.03 \mathrm{MHz}$ ) again two doublet at 6.42 and $6.90 \mathrm{ppm}$ are due to presence of $\mathrm{OH}$ at $\mathrm{C}-5$ and $\mathrm{C}-7$ position $(J=1.06$ and 1.04$)$, respectively. The multiplet at $7.56 \mathrm{ppm}$ is due to $2^{\prime} 1 \mathrm{H}$ of the phenyl ring substituted at 2-position of the coumarin moiety $(J=1.00 \mathrm{MHz})$. The doublet at $7.68 \mathrm{ppm}$ is due to one proton present in the substituted phenyl ring at $\mathrm{C}-5^{\prime}$ position. Singlet at $9.32 \mathrm{ppm}$ is due to the $1 \mathrm{H}$ at C-6 $6^{\prime}$ position. The singlet peak at $10.81 \mathrm{ppm}$ and $12.48 \mathrm{ppm}$ are due to presence of $\mathrm{C}-\mathrm{OH}$ proton at C-3' and C-4' position.

\begin{tabular}{|c|c|c|c|}
\hline \multicolumn{4}{|c|}{$\begin{array}{c}\text { TABLE-2 } \\
{ }^{1} \mathrm{H} \text { AND }{ }^{13} \mathrm{C} \text { NMR SPECTRAL DATA OF ISOLATED } \\
\text { COMPOUND FROM METHANOLIC EXTRACT OF } \\
\text { Mirabilis jalapa } \text { Linn. TUBER }\end{array}$} \\
\hline Position of $\mathrm{H} / \mathrm{C}$ & Department & Value of $\delta_{\mathrm{H}}$ & Values of $\delta_{\mathrm{C}}$ \\
\hline 2 & $\mathrm{C}$ & & 93.33 \\
\hline 3 & $\mathrm{C}-\mathrm{OH}$ & 6.19 & 135.68 \\
\hline 4 & $\mathrm{C}=\mathrm{O}$ & & 102.98 \\
\hline 5 & $\mathrm{C}-\mathrm{OH}$ & 6.90 & 145 \\
\hline 6 & $\mathrm{CH}$ & 2.50 & 98.15 \\
\hline 7 & $\mathrm{C}-\mathrm{OH}$ & 6.42 & 146.76 \\
\hline 8 & $\mathrm{CH}$ & 3.53 & 115.03 \\
\hline 9 & $\mathrm{C}$ & & 115.57 \\
\hline 10 & $\mathrm{C}$ & & 119.97 \\
\hline $\mathbf{1}^{\prime}$ & $\mathrm{C}$ & & 121.94 \\
\hline 2 & $\mathrm{CH}$ & 7.56 & 147.64 \\
\hline $3^{\prime}$ & $\mathrm{C}-\mathrm{OH}$ & 10.81 & 163.82 \\
\hline $4^{\prime}$ & $\mathrm{C}-\mathrm{OH}$ & 12.48 & 175.78 \\
\hline $5^{\prime}$ & $\mathrm{CH}$ & 7.68 & 156.11 \\
\hline $6^{\prime}$ & $\mathrm{CH}$ & 9.32 & 160.57 \\
\hline
\end{tabular}

${ }^{13} \mathrm{C}$ NMR spectrum (Table-2) of the compound revealed the presence of 15 carbons. Signal at $\delta 175.9$ in the ${ }^{13} \mathrm{C}$ NMR spectrum indicates the presence of conjugated carbonyl group in the compound. The prominent peak at $93.33,98.15$ coresponse to the carbon atom at position 2 and 6 , respectively. The peak at 102.98 corresponds for $\mathrm{C}-(\mathrm{C}=\mathrm{O})$ at positon 4 , the peak at $135.68,145$ and 146.76 corresponds to carbon atoms $(\mathrm{C}-\mathrm{OH})$ at position 3, 5, 7, repectively. The prominent peak at 115.03 corresponds to the carbon atom at position 8 . The peaks at 115.57 and 119.97 are due to the fused carbon between the two rings of chromen nucleus at position 9 and 10 . The prominent peak at 163.82 and 175.78 is due to the $\mathrm{C}$ atom $(\mathrm{C}-\mathrm{OH})$ at position $3^{\prime}$ and $4^{\prime}$ of substituted phenyl ring. Peak at 121.94 depict the C-atom at $1^{\prime}$ position. Finally, peak at 174.64, 156.11 and 160.57 is due to the carbon atom $(\mathrm{CH})$ at position $2^{\prime}, 5^{\prime}, 6^{\prime}$, repectively.

On the basis of physical properties and spectroscopic data, structure of compound was identified as $2-\left(3^{\prime}, 4^{\prime}\right.$-dihydroxy phenyl)-3,5,7-trihydroxy chromen 4-one.

Cardioprotective activity of methanolic extract and isolated compound of Mirabilis jalapa tuber: Doxorubicin produced cardiotoxicity by chronic administration [24]. In present study, it was established that the different doses of Mirabilis jalapa and isolated product of Mirabilis jalapa were revealed the significant increase in cardiac biomarker enzymes and endogenous antioxidants and heart tissue histolopathology.

Cardiac tissue is especially susceptible to free radical injury, because of the lower activities of the free radical detoxifying mechanisms, such as SOD, CAT and GSH [25]. Further, doxorubicin also has a high affinity for the phospholipid component of the mitochondrial membrane in cardiac myocytes, leading to selective accumulation of doxorubicin in the heart tissue $[26,27]$. The doxorubicin-induced mitochondrial injury is critical to the heart because it would presumably have extreme adverse effects on the contractile functioning of the cardiac myocytes by producing alterations in the energy metabolism [28,29].

Serum lipid levels: The result shown that animal treated with DOX (5 mg/kg b.w. i.p.) stimulated cardiotoxicity and showed the increase levels of cholesterol, triglyceride and LDL and reduce level of HDL when compared with normal control. However, it was also observed that Mirabilis jalapa tuber treated groups with dose at 200 and $400 \mathrm{mg} / \mathrm{kg}$ b.w. and isolated product at $5.56 \mathrm{mg} / \mathrm{kg}$ bw significantly $(* \mathrm{p}<0.05)$ decreased of level of cholesterol, triglyceride and LDL. But only the dose of $400 \mathrm{mg} / \mathrm{kg}$ b.w. Mirabilis jalapa increased the level of HDL when compared with doxorubicin control group where as dose $100 \mathrm{mg} / \mathrm{kg}$ b.w. was found to be not significant compared to high doses (Table-3).

Serum enzyme biomarkers: Animals treated with doxorubicin ( $5 \mathrm{mg} / \mathrm{kg}$ b.w. i.p.) reported the increase in the levels of 
TABLE-3

EFFECT OF Mirabilis jalapa TUBER AND ITS ISOLATED PRODUCT ON CHOLESTEROL, TRIGLYCERIDES, HDL AND LDL LEVEL IN DOXORUBICIN TREATED RAT (MEAN \pm SEM, $n=6)$

\begin{tabular}{|c|c|c|c|c|c|c|c|c|c|}
\hline Groups & Treatment & $\begin{array}{l}\text { Cholesterol } \\
\left(\mathrm{mg} \mathrm{dL}^{-1}\right)\end{array}$ & $\begin{array}{c}\text { Cholesterol } \\
\text { decrease } \\
(\%)\end{array}$ & $\begin{array}{l}\text { Triglyceride } \\
\left(\mathrm{mg} \mathrm{dL}^{-1}\right)\end{array}$ & $\begin{array}{c}\text { Triglyceride } \\
\text { decrease } \\
(\%)\end{array}$ & $\begin{array}{c}\mathrm{HDL} \\
\left(\mathrm{mg} \mathrm{dL}^{-1}\right)\end{array}$ & $\begin{array}{c}\text { HDL } \\
\text { increase } \\
(\%)\end{array}$ & $\begin{array}{c}\mathrm{LDL} \\
\left(\mathrm{mg} \mathrm{dL}^{-1}\right)\end{array}$ & $\begin{array}{c}\text { LDL } \\
\text { decrease } \\
(\%)\end{array}$ \\
\hline I & $\begin{array}{l}\text { Doxorubicin }(5 \mathrm{mg} / \mathrm{kg}) \\
\text { control }\end{array}$ & $\begin{array}{l}286.27 \pm \\
34.25\end{array}$ & - & $\begin{array}{l}205.69 \pm \\
26.75\end{array}$ & - & $\begin{array}{l}12.69 \pm \\
2.93\end{array}$ & - & $\begin{array}{l}185.87 \pm \\
25.93\end{array}$ & - \\
\hline II & Normal control & $\begin{array}{l}88.60 \pm \\
5.96^{* * * *}\end{array}$ & 69.00 & $\begin{array}{l}69.76 \pm \\
3.18^{* * *}\end{array}$ & 66.08 & $\begin{array}{l}46.73 \pm \\
6.26^{* * * *}\end{array}$ & 268.24 & $\begin{array}{l}52.14 \pm \\
8.45^{* * * *}\end{array}$ & 71.94 \\
\hline III & $\begin{array}{l}\text { Mirabilis jalapa }(100 \\
\mathrm{mg} / \mathrm{kg})+ \text { Doxorubicin }\end{array}$ & $\begin{array}{c}244.21 \pm \\
28.96^{\mathrm{ns}}\end{array}$ & 14.69 & $\begin{array}{c}183.14 \pm \\
21.37^{\text {ns }}\end{array}$ & 10.96 & $\begin{array}{c}13.80 \pm \\
4.98^{\text {ns }}\end{array}$ & 8.74 & $\begin{array}{c}172.65 \pm \\
26.54^{\text {ns }}\end{array}$ & 7.11 \\
\hline IV & $\begin{array}{l}\text { Mirabilis jalapa }(200 \\
\mathrm{mg} / \mathrm{kg})+ \text { Doxorubicin }\end{array}$ & $\begin{array}{l}177.71 \pm \\
22.27^{* *}\end{array}$ & 37.92 & $\begin{array}{c}133.45 \pm \\
17.97^{*}\end{array}$ & 35.98 & $\begin{array}{c}21.78 \pm \\
5.56^{\mathrm{ns}}\end{array}$ & 71.63 & $\begin{array}{c}104.64 \pm \\
17.55^{*}\end{array}$ & 43.70 \\
\hline V & $\begin{array}{l}\text { Mirabilis jalapa }(400 \\
\mathrm{mg} / \mathrm{kg})+ \text { Doxorubicin }\end{array}$ & $\begin{array}{l}99.72 \pm \\
8.03^{* * * *}\end{array}$ & 65.16 & $\begin{array}{l}82.76 \pm \\
8.93^{* * * *}\end{array}$ & 59.76 & $\begin{array}{l}35.53 \pm \\
4.56^{*}\end{array}$ & 179.98 & $\begin{array}{l}65.70 \pm \\
12.41^{* * *}\end{array}$ & 64.65 \\
\hline VI & $\begin{array}{l}\text { Isolated product of } \\
\text { Mirabilis jalapa }(5.56 \\
\mathrm{mg} / \mathrm{kg})+ \text { Doxorubicin }\end{array}$ & $\begin{array}{c}127.85 \pm \\
9.16^{* * * *}\end{array}$ & 55.33 & $\begin{array}{c}108.67 \pm \\
5.94^{* *}\end{array}$ & 47.16 & $\begin{array}{c}28.16 \pm \\
6.31^{\mathrm{ns}}\end{array}$ & 121.90 & $\begin{array}{l}88.28 \pm \\
13.71^{* *}\end{array}$ & 52.50 \\
\hline
\end{tabular}

All results are expressed as Mean \pm SEM ( $n=6$ in each group). Statistical comparison was determined by one way ANOVA followed by the Dunnett's comparison tests. ${ }^{*} \mathrm{p}<0.05, * * \mathrm{p}<0.01,{ }^{* *} \mathrm{p}<0.001$ significant; $\mathrm{ns}=$ not significant when compared with control.

creatine phosphokinase (CPK), LDH, aspartate transaminase (AST) and alanine transaminase (ALT) as compared to normal control group. After treatment with Mirabilis jalapa at higher dose of 200 and $400 \mathrm{mg} / \mathrm{kg}$ b.w. as well as isolated product of Mirabilis jalapa ( $5.56 \mathrm{mg} / \mathrm{kg}$ b.w.), the level of creatine phosphokinase (CPK), LDH, aspartate transaminase (AST) and alanine transaminase (ALT) significantly restored towards normal in dose dependent manner where as dose $100 \mathrm{mg} / \mathrm{kg}$ bw was found to be not significant compared to high doses (Table-4). This could be due to a protective or membrane-stabilizing effect of extract and isolated compound on the myocardium, reducing the cardiac damage, and thereby restricting the leakage of these enzymes [30,31].

Antioxidant status: Effect of doxorubicin on tissue lipid peroxidation, antioxidant and antioxidant enzymes are shown in Table-5. The malondialdehyde (MDA) level was increased whereas endogenous non-enzymatic (GSH) and enzymatic (SOD and CAT) levels were significantly decreased in doxorubicin treated group as compared to normal animals. At higher dose of Mirabilis jalapa at 200 and $400 \mathrm{mg} / \mathrm{kg}$ b.w. and isolated compound of Mirabilis jalapa at $5.56 \mathrm{mg} / \mathrm{kg}$ b.w. produced significant decrease in the level of MDA and increase the level of GSH and CAT as compared with doxorubicin control group but level of SOD significant decrease with Mirabilis jalapa at $400 \mathrm{mg} / \mathrm{kg}$ b.w. dose when compared with doxorubicin control group.

The present study has shown that administration of extracts at high doses and isolated compound efficiently counter acted the doxorubicin induced cardiac tissue damage by significant decrease in MDA and elevated the GSH content to near-normal levels, which prevented degradation of cellular macromolecules and thus cell disruption, probably by decreasing $\mathrm{Ca}^{2+}$ influx [32] and also increase in GSH, SOD and CAT levels [33]. These results indicated the protective effect of Mirabilis jalapa and isolated compound on doxorubicin-induced cardiotoxicity by boosting the endogenous non-enzymatic and enzymatic antioxidant systems, which entailed scavenging of oxidative free radicals.

Histopathological observation: Histopathological assessment of heart tissue are represented in Fig. 1. The results illustrated that the heart tissue from normal control treated animal showed

TABLE-4

EFFECT OF Mirabilis jalapa TUBER AND ITS ISOLATED PRODUCT ON CPK, LDH, AST AND ALT IN DOXORUBICIN TREATED RAT (MEAN \pm SEM, $\mathrm{n}=6)$

\begin{tabular}{|c|c|c|c|c|c|c|c|c|c|}
\hline Groups & Treatment & $\begin{array}{c}\mathrm{CPK} \\
\left(\mathrm{IU} \mathrm{L}^{-1}\right)\end{array}$ & $\begin{array}{c}\text { CPK } \\
\text { decrease } \\
(\%)\end{array}$ & $\begin{array}{l}\mathrm{LDH} \\
\left(\mathrm{IU} \mathrm{L}^{-1}\right)\end{array}$ & $\begin{array}{c}\mathrm{LDH} \\
\text { decrease } \\
(\%)\end{array}$ & $\begin{array}{l}\mathrm{AST} \\
\left(\mathrm{IU} \mathrm{L}^{-1}\right)\end{array}$ & $\begin{array}{c}\text { AST } \\
\text { decrease } \\
(\%)\end{array}$ & $\begin{array}{c}\mathrm{ALT} \\
\left(\mathrm{IU} \mathrm{L}^{-1}\right)\end{array}$ & $\begin{array}{c}\text { ALT } \\
\text { decrease } \\
(\%)\end{array}$ \\
\hline I & $\begin{array}{l}\text { Doxorubicin }(5 \mathrm{mg} / \mathrm{kg}) \\
\text { control }\end{array}$ & $\begin{array}{l}356.66 \pm \\
37.28\end{array}$ & - & $\begin{array}{l}285.79 \pm \\
28.10\end{array}$ & - & $\begin{array}{c}128.87 \pm \\
17.94\end{array}$ & - & $\begin{array}{c}89.60 \pm \\
12.20\end{array}$ & - \\
\hline II & Normal control & $\begin{array}{l}94.49 \pm \\
9.12^{* * * *}\end{array}$ & 73.50 & $\begin{array}{l}122.46 \pm \\
16.83^{* * * *}\end{array}$ & 57.15 & $\begin{array}{l}42.54 \pm \\
6.25^{* * * *}\end{array}$ & 66.98 & $\begin{array}{l}28.67 \pm \\
5.69^{* * * *}\end{array}$ & 68.00 \\
\hline III & $\begin{array}{l}\text { Mirabilis jalapa }(100 \\
\mathrm{mg} / \mathrm{kg})+ \text { Doxorubicin }\end{array}$ & $\begin{array}{c}298.30 \pm \\
41.58^{\text {ns }}\end{array}$ & 16.36 & $\begin{array}{c}201.45 \pm \\
32.84^{\text {ns }}\end{array}$ & 29.51 & $\begin{array}{c}125.77 \pm \\
19.50^{\text {ns }}\end{array}$ & 2.40 & $\begin{array}{l}61.71 \pm \\
8.68^{\text {ns }}\end{array}$ & 31.12 \\
\hline IV & $\begin{array}{l}\text { Mirabilis jalapa }(200 \\
\mathrm{mg} / \mathrm{kg})+ \text { Doxorubicin }\end{array}$ & $\begin{array}{l}191.74 \pm \\
35.07^{* *}\end{array}$ & 46.24 & $\begin{array}{l}161.26 \pm \\
23.71^{* * *}\end{array}$ & 43.57 & $\begin{array}{c}82.47 \pm \\
8.43^{*}\end{array}$ & 36.00 & $\begin{array}{c}45.03 \pm \\
6.08^{* * *}\end{array}$ & 49.74 \\
\hline V & $\begin{array}{l}\text { Mirabilis jalapa }(400 \\
\mathrm{mg} / \mathrm{kg})+ \text { Doxorubicin }\end{array}$ & $\begin{array}{l}111.98 \pm \\
14.59^{* * * * *}\end{array}$ & 68.60 & $\begin{array}{l}131.91 \pm \\
14.71^{* * * * *}\end{array}$ & 53.84 & $\begin{array}{l}52.55 \pm \\
6.57^{* * * * *}\end{array}$ & 59.22 & $\begin{array}{l}33.74 \pm \\
3.75^{* * * *}\end{array}$ & 62.34 \\
\hline VI & $\begin{array}{l}\text { Isolated product of } \\
\text { Mirabilis jalapa }(5.56 \\
\mathrm{mg} / \mathrm{kg})+ \text { Doxorubicin }\end{array}$ & $\begin{array}{l}161.74 \pm \\
9.65^{* * * *}\end{array}$ & 54.65 & $\begin{array}{c}148.46 \pm \\
9.73^{* * * *}\end{array}$ & 48.05 & $\begin{array}{c}69.53 \pm \\
5.46^{* *}\end{array}$ & 46.04 & $\begin{array}{l}41.57 \pm \\
5.64^{* * *}\end{array}$ & 53.60 \\
\hline
\end{tabular}

All results are expressed as Mean \pm SEM ( $n=6$ in each group). Statistical comparison was determined by one way ANOVA followed by the Dunnett's comparison tests. ${ }^{*} \mathrm{p}<0.05,{ }^{*} \mathrm{p}<0.01,{ }^{* *} \mathrm{p}<0.001$ significant; $\mathrm{ns}=$ not significant when compared with control. 


\begin{tabular}{|c|c|c|c|c|c|c|c|c|c|}
\hline \multicolumn{10}{|c|}{$\begin{array}{c}\text { TABLE-5 } \\
\text { EFFECT OF Mirabilis jalapa TUBER AND ITS ISOLATED PRODUCT ON MDA, GSH, } \\
\text { AND SOD LEVEL IN DOXORUBICIN TREATED RAT (MEAN } \pm \text { SEM, } \mathrm{n}=6)\end{array}$} \\
\hline Groups & Treatment & $\begin{array}{l}\text { MDA (n } \\
\mathrm{mol} / \mathrm{g} \text { of } \\
\text { wet } \\
\text { tissue })\end{array}$ & $\begin{array}{l}\text { MDA } \\
\text { decrease } \\
(\%)\end{array}$ & $\begin{array}{l}\text { GSH } \\
(\mu \mathrm{g} / \mathrm{g} \text { of } \\
\text { wet } \\
\text { tissue })\end{array}$ & $\begin{array}{l}\text { GSH } \\
\text { increase } \\
(\%)\end{array}$ & $\begin{array}{l}\text { CAT } \\
\text { (unit/mg } \\
\text { of } \\
\text { protein) }\end{array}$ & $\begin{array}{l}\text { CAT } \\
\text { increase } \\
(\%)\end{array}$ & $\begin{array}{l}\text { SOD } \\
\text { (unit/mg } \\
\text { of } \\
\text { protein) }\end{array}$ & $\begin{array}{l}\text { SOD } \\
\text { increase } \\
(\%)\end{array}$ \\
\hline I & $\begin{array}{l}\text { Doxorubicin }(5 \mathrm{mg} / \mathrm{kg}) \\
\text { control }\end{array}$ & $\begin{array}{l}65.19 \pm \\
8.38\end{array}$ & - & $\begin{array}{l}1.23 \pm \\
0.047\end{array}$ & - & $\begin{array}{c}16.04 \pm \\
3.42\end{array}$ & - & $\begin{array}{l}11.92 \pm \\
2.92\end{array}$ & - \\
\hline II & Normal control & $\begin{array}{l}11.77 \pm \\
3.04^{* * *}\end{array}$ & 81.94 & $\begin{array}{l}3.96 \pm \\
0.42^{* * *}\end{array}$ & 221.95 & $\begin{array}{l}48.76 \pm \\
5.88^{* * *}\end{array}$ & 203.99 & $\begin{array}{l}32.22 \pm \\
4.834^{* * *}\end{array}$ & 170.30 \\
\hline III & $\begin{array}{l}\text { Mirabilis jalapa }(100 \mathrm{mg} / \mathrm{kg}) \\
+ \text { Doxorubicin }\end{array}$ & $\begin{array}{c}60.15 \pm \\
9.25^{\text {ns }}\end{array}$ & 7.73 & $\begin{array}{l}1.26 \pm \\
0.34^{\mathrm{ns}}\end{array}$ & 2.43 & $\begin{array}{c}16.43 \pm \\
2.23^{\text {ns }}\end{array}$ & 2.43 & $\begin{array}{c}12.08 \pm \\
1.16^{\mathrm{ns}}\end{array}$ & 1.34 \\
\hline IV & $\begin{array}{l}\text { Mirabilis jalapa }(200 \mathrm{mg} / \mathrm{kg}) \\
\text { + Doxorubicin }\end{array}$ & $\begin{array}{l}38.79 \pm \\
5.82^{*}\end{array}$ & 32.82 & $\begin{array}{l}2.52 \pm \\
0.45^{*}\end{array}$ & 104.87 & $\begin{array}{c}22.58 \pm \\
3.43^{\text {ns }}\end{array}$ & 40.77 & $\begin{array}{c}17.76 \pm \\
2.37^{\text {ns }}\end{array}$ & 48.99 \\
\hline V & $\begin{array}{l}\text { Mirabilis jalapa }(400 \mathrm{mg} / \mathrm{kg}) \\
\text { + Doxorubicin }\end{array}$ & $\begin{array}{l}21.77 \pm \\
4.76^{* * *}\end{array}$ & 66.60 & $\begin{array}{l}2.94 \pm \\
0.31^{* *}\end{array}$ & 139.02 & $\begin{array}{c}35.55 \pm \\
4.60^{*}\end{array}$ & 121.63 & $\begin{array}{c}24.47 \pm \\
2.56^{*}\end{array}$ & 105.28 \\
\hline VI & $\begin{array}{l}\text { Isolated product of Mirabilis } \\
\text { jalapa }(5.56 \mathrm{mg} / \mathrm{kg})+ \\
\text { Doxorubicin }\end{array}$ & $\begin{array}{l}28.70 \pm \\
3.74^{* *}\end{array}$ & 55.59 & $\begin{array}{l}2.56 \pm \\
0.24^{*}\end{array}$ & 108.13 & $\begin{array}{l}32.96 \pm \\
5.63^{*}\end{array}$ & 105.48 & $\begin{array}{c}19.48 \pm \\
4.13^{\text {ns }}\end{array}$ & 63.42 \\
\hline
\end{tabular}

All results are expressed as Mean \pm S.E.M ( $n=6$ in each group). Statistical comparison was determined by one way ANOVA followed by the Dunnett's comparison tests. ${ }^{*} \mathrm{p}<0.05, * * \mathrm{p}<0.01, * * * \mathrm{p}<0.001$ significant; $\mathrm{ns}=$ not significant when compared with control (Doxorubicin 5 $\mathrm{mg} / \mathrm{kg}$ ).

normal morphological appearances whereas doxorubicin treated animal caused disorganization of normal cellular structure of heart like loss of myofibrils, vacuolization of the cytoplasm, inflammatory cell infiltration or necrosis were observed. On the other hand, the treatment with Mirabilis jalapa at dose 200 and $400 \mathrm{mg} / \mathrm{kg}$ b.w. as well isolated compound Mirabilis jalapa $(5.56 \mathrm{mg} / \mathrm{kg}$ b.w.) shown significantly reduced the histopathological changes in the cardiac tissue took place due to doxorubicin (control) admistration and recovered almost normal histological appearance of cardiac muscle similar to that of normal control. The dose at $100 \mathrm{mg} / \mathrm{kg}$ b.w. did not show any significant effect on doxorubicin treated animal.
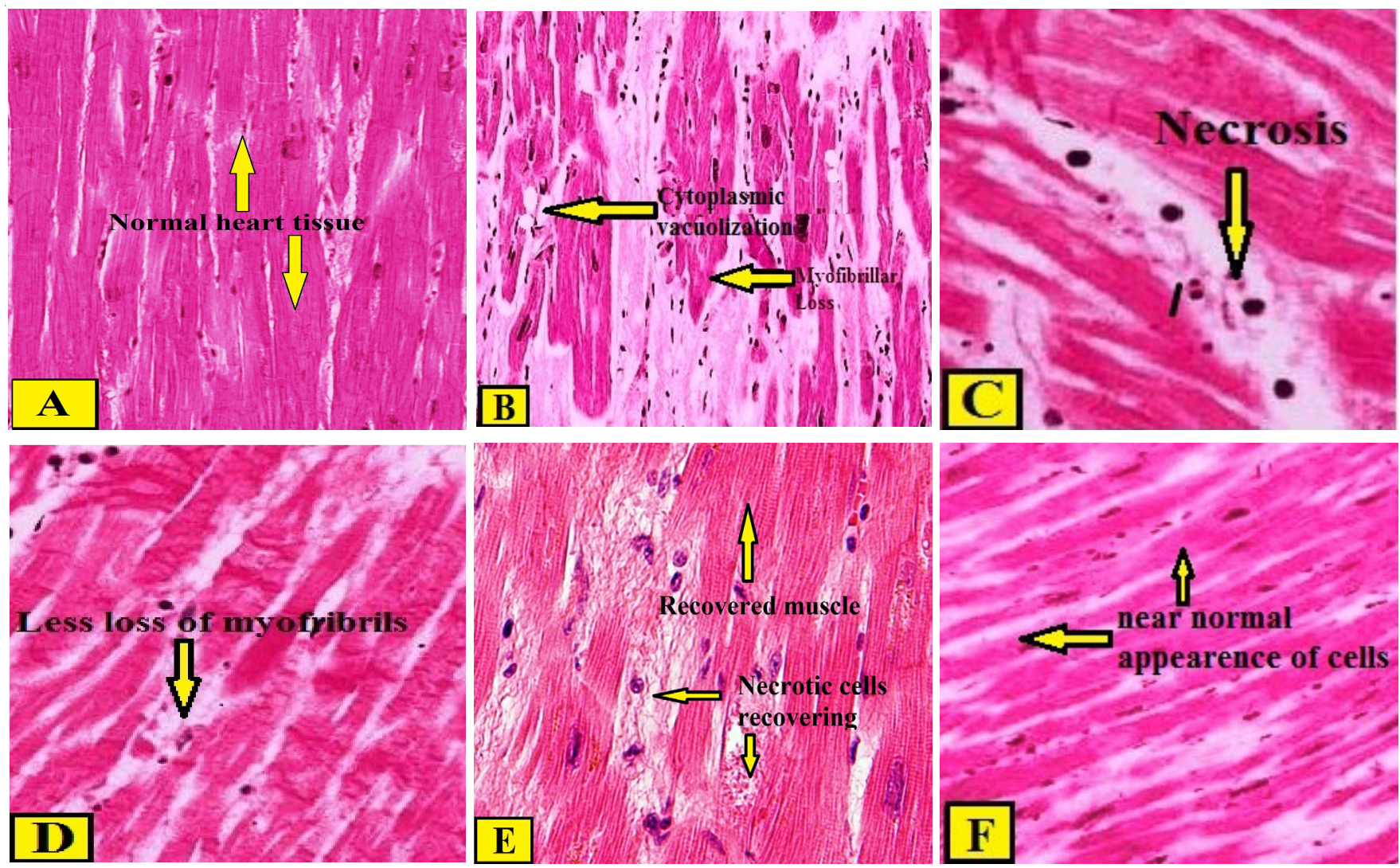

Fig. 1. Histological section [10x and 40x magnification] of the cardiac tissue. Control groups (A) presented normal architecture of cardiac tissue. Doxorubicin-treated group (B) shown degenerative changes including myofibrillar loss, cytoplasmic vacuolization, inflammatory cell infiltration. Extract dose at $100 \mathrm{mg} / \mathrm{kg}$ bw (C) shown almost similar appearance that of doxorubicin control (B). Extract treatment groups with dose $200 \mathrm{mg} / \mathrm{kg}$ bw (D) and $400 \mathrm{mg} / \mathrm{kg}$ bw (E) and isolated compound (F) at dose $5.56 \mathrm{mg} / \mathrm{kg}$ bw shown significantly reduced doxorubicin-induced degenerative changes and recovered the cardiac cells similar to that of normal control (A) 


\section{Conclusion}

Flavonoid (2-(3',4'-dihydroxy phenyl)-3,5,7-trihydroxy chromen-4-one was isolated and characterized from methanolic extract of Mirabilis jalapa tuber. Therefore, from the results it can be stated that the cardioprotective activity of plant part of Mirabilis jalapa is due to the presence of flavonoid.

\section{REFERENCES}

1. V.P. Silja, K.S. Verma and K.V. Mohan, Indian J. Tradit. Knowl., 7, 604 (2008).

2. J.W. Prakash, Indian J. Tradit. Knowl., 7, 410 (2008).

3. K.V. Kiran, S.N. Ravi, S. Ramya, R.V. Sahaja, K. Saritha, R.K. Govinda and N.V. Naidu, Int. J. Phytomed., 2, 402 (2010).

4. N.S. Mahajan, R.L. Jadhav, N.V. Pimpodkar, R.J. Dias and S.B. Garje, J. Pharm. Res., 1, 159 (2008).

5. D. Shil, S. Dash and D. Laloo, Int. J. Res. Pharm. Sci., 8, 339 (2007).

6. S. Suroowan and F. Mahomoodally, Clin. Phytosci., 1, 1 (2015); https://doi.org/10.1186/s40816-015-0002-3.

7. K.R. Khandelwal, Practical Pharmacognosy: Techniques and Experiments, Nirali Prakashan, Pune, India, pp. 25.2-25.9 (2012).

8. C.K. Kokate, A.P. Purohit and G.B. Gokhale, Pharmacognosy, Nirali Prakashan, Pune, India, pp. 123-124 (2014).

9. H. Wagner and S. Bladt, Plant Drug Analysis: A Thin Layer Chromatography Atlas, Springer, Thomas Press India Ltd., New Delhi, pp. 1-2 (2004).

10. E.M. Rani, K. Shilpa and V. Umamaheswara Rao, Int. J. Pharm. Res. Anal., 4, 328 (2014)

11. Organization for Economic Cooperation and Development (OECD) Guidelines for Acute Toxicity of Chemicals, No. 425 (2008).

12. A. Kundu, A. Ghosh, N.K. Singh, G.K. Singh, A. Seth, S.K. Maurya, S. Hemalatha and D. Laloo, Pharm. Biol., 54, 2383 (2016); https://doi.org/10.3109/13880209.2016.1157192.

13. N.R. Barman, P.K. Kar, P.K. Hazam, H.S. Pal, A. Kumar, S. Bhattacharya and P.K. Haldar, Chin. J. Nat. Med., 11, 38 (2013); https://doi.org/10.1016/S1875-5364(13)60005-9.

14. J. King, ed.: D. Van, The Dehydrogenases or Oxidoreductase-Lactate Dehydrogenase In: Practical Clinical Enzymology, Van Nostrand, London, p. 106 (1965).

15. S. Okinaka, H. Kumaggai, S. Ebashi, H. Sugita, H. Momoi, Y. Toyokura and Y. Fujie, Arch. Neurol., 4, 520 (1961); https://doi.org/10.1001/archneur.1961.00450110050006.
16. S. Kaviarasan and C.V. Anuradha, Pharmazie, 62, 299 (2007); https://doi.org/10.1691/ph.2007.4.6648.

17. W. Richmond, Clin. Chem., 19, 1350 (1973).

18. G.A. Beaulah, A.M. Sadiq, V. Sivakumar and R.J. Santhi, J. Med. Plants Stud., 2, 1 (2014).

19. M.K. Singh, M. Faisal, A. Ahmad, A. Sonkar and and J. Yadav, Int. J. Drug Develop. Res., 4, 298 (2012).

20. H. Ohkawa, N. Ohishi and K. Yagi, Anal. Biochem., 95, 351 (1979); https://doi.org/10.1016/0003-2697(79)90738-3.

21. S. Marklund, ed.: R.A. Greenwald, Pyrogallol Autoxidation: Handbook of Methods for Oxygen Radical Research,CRC Press, Boca Raton, pp. 243-247 (1985).

22. H. Aebi, ed.: H.U. Bergmeyer, Catalase: Methods of Enzymatic Analysis, Chemic Academic Press Inc., Verlag, 673-685 (1974).

23. G.L. Ellman, Arch. Biochem. Biophys., 82, 70 (1959); https://doi.org/10.1016/0003-9861(59)90090-6.

24. R. Hrdina, V. Gersl, I. Klimtova, T. Simunek, J. Machackova and M. Adamcova, Acta Medica (Cordoba), 43, 75 (2000).

25. L. Gille and N. Hans, Free Radic. Biol. Med., 23, 775 (1997); https://doi.org/10.1016/S0891-5849(97)00025-7.

26. I. Taks, B. Matkovics, S. Varga, P. Homolay, G. Feher and T. Seres, Pharmacol. Res., 25, 177 (1992); https://doi.org/10.1016/1043-6618(92)90348-F

27. E.Y. Wu, M.T. Smith, G. Bellomo and D. Di Monte, Arch. Biochem. Biophys., 282, 358 (1990); https://doi.org/10.1016/0003-9861(90)90129-M

28. X. Liu, Z. Chen, C.C. Chua, Y.S. Ma, G.A. Youngberg, R. Hamdy and B.H.L. Chua, Am. J. Physiol.: Heart Circ. Physiol., 283, H254 (2002); https://doi.org/10.1152/ajpheart.01023.2001.

29. K.K.M. Ahmed, A.C. Rana and V.K. Dixit, Phytomedicine, 11, 327 (2004); https://doi.org/10.1078/0944711041495146.

30. Y. Murat, F. Ersin, E. Hasan, U. Muharrem, S. Sadik and M.K. Irmak, Pharmacol. Res., 48, 377 (2003); https://doi.org/10.1016/S1043-6618(03)00185-3.

31. B.C. Koti, A.H. Vishwanathswamy and W. Jyoti, Indian J. Exp. Biol., 47, 41 (2009).

32. A.H.M. Thippeswamy, A. Shirodkar, B.C. Koti, A.J. Sadiq, D.M. Praveen, A.V. Swamy and M. Patil, Indian J. Pharmacol., 43, 31 (2011); https://doi.org/10.4103/0253-7613.75663.

33. S. Bhattacharya, A. Prasanna, P. Majumdar, R.B.S. Kumar and P.K. Haldar, Pharm. Biol., 49, 927 (2011); https://doi.org/10.3109/13880209.2011.557080. 